\section{Presentation to Dr. R. R. Marett}

A volume of anthropological essays by friends and former pupils, entitled "Custom is King", a notice of which appears on p. 1014, was presented to Dr. R. R. Marett, Rector of Exeter College, Oxford, and reader in social anthropology in that University, on June 13, to mark the occasion of his seventieth birthday. The presentation was made in the College Hall by an undergraduate, and was attended by the ViceChancellor, a number of heads of houses and professors. The chair was taken by Sir Charles Harper, a former pupil. In acknowledging the presentation, Dr. Marett reminded his hearers that, as the University had claimed three quarters of his time in his main business of philosophy, only one quarter had been available for the claims of anthropology, while his books had been written in vacation. In speaking of anthropology in the University of Oxford, he referred to the late Arthur Thomson and to Henry Balfour. With himself they had been 'three men in a boat', of whom it was possible to say that no one was captain; and to them had been added Dr. L. H. Dudley Buxton, and later Mr. T. K. Penniman, as cabin boys. In conclusion, he spoke of the termination of his long tenure of the readership in social anthropology, and rejoiced that Oxford at last was to have a full professorship in anthropology.

IT is scarcely necessary to recall how great is the debt of anthropology in Oxford to Dr. Marett. With the exception of Sir Edward Tylor, who of course stands apart from and above all, this branch of academic studies, perhaps, owes more to him than to any single individual-oven though the great services of the late Arthur Thomson and Henry Balfour be not forgotten. Long before the contemplation of the manners and customs of 'savages' had been raised to the dignity of forming part of an official course, his lectures on ethics and psychology had directed many of his pupils to this pleasing intellectual adventure; and not only did he take a foremost part in the movement which led to the institution of a diploma in anthropology, but also, as secretary for twenty years of the committee responsible in the University for this subject, he imposed his broad and philosophic outlook on the Oxford school of anthropological thought.

\section{Plants and Medicine}

THE lecture which commemorates annually Sir Edwin Chadwick, "the father of English sanitation", was this year given at the Chelsea Physic Garden by Sir William Willcox on June 11. In choosing "Plant Pharmacology and Medical Practice" for his subject, Sir William might well have been excused from dealing with synthetic chemical medicaments; he nevertheless claimed as plant products "coal and coal tar with its myriads of derivatives", a claim which suggests a perilous affinity between rhubarb and the barbiturates. It seems a strong thing to hold, as Sir William Willcox is prepared to do, that "plant products rarely act as tissue poisons because of their purity . . (while) in the chemical laboratory the conditions are so different from those obtaining in Nature that by-products injurious to health always occur during any chemical synthesis", and that "it is for this reason that so many of the modern artificially synthesised drugs are liver and tissue poisons : examples are cinchophen and similar derivatives". Nevertheless, it is certain that if in recent years orthodox medicine has preferred the synthetic product of the laboratory, the public have turned in increasing measure to herbal remedies, and there has been a large increase in the numbers of herbal stores and in the trade in herbal medicines. The benefit derived from drinking several pints of hot water daily in the form of a tisane or decoction may be substantial, and certainly the danger of positive harm is minute compared with the results of uncontrolled resort to the tonics, sleeping-draughts, digestive pills and headache tablets which are a by-product of modern civilisation. The representative exhibition of medicinal plants shown at the lecture served to link the Physic Garden of to-day with its beginnings in the seventeenth century, when it supplied the apothecaries of London with those herbs which they failed to collect on their 'herbarizing' expeditions in the fields of Greenwich and Battersea.

\section{English Death Rates}

THE retiring president of the Royal Statistical Society, Prof. Major Greenwood, took for the subject of his valedictory address, read on June 16, "English Death Rates, Past, Present and Future". Prof. Greenwood pointed out that down to the beginning of the twentieth century, there was no improvement in mortality at the beginning of life and little improvement in old age, but that since the turn of the century there had been great improvement in the mortality of little children and some improvement in old age. From the beginning of registration, rates of mortality at ages between early childhood and old age improved, but the improvement began in time with the earlier ages and seemed to pass like a wave down the ages. In the opinion of some students, this wave-like movement was determined by the course of social reform, first directed to the protection of the young and only later to that of adults; Farr attributed the slow improvement of the rates of mortality in his time to the growth of towns; in his view, the general social and hygienic reforms of his time were offset by the disadvantages of density of population. Modern students, notably Kermack, McKendrick and McKinlay, have objected that the wave of improvement is too regular to be explained in these ways and suggested that the prime factor regulating mortality rates is the environment of childhood. Prof. Greenwood concludes that, even if this hypothesis does not completely explain the whole movement, it furnishes an important element of truth, so that contemporary emphasis upon the paramount importance of caring for the young is properly placed. This does not, of course, lead to the pessimistic conclusion that measures directed to the improvement of the conditions of life of adults are useless ; there is much evidence that they are of value. Thus, the 
problem of cancer is not one which the general statistician can view with much pleasure, "but a perusal of clinical records and of the last report of the Director of the Imperial Cancer Research Fund gives some grounds for optimism".

\section{The Imperial Institute and Vegetable Fibres}

We are indebted to Dr. E. Goulding for an account of forty years of investigation of vegetable fibres at the Imperial Institute, which was the subject of the Mather Lecture delivered by him during the annuel Conference of the Textile Institute on June 3-5 in London. A record such as this emphasises the importance and value of the Imperial Institute to the Empire as a whole. Individual technical reports go to all parts of the Empire, but usually each country is concerned only with those which emanate from itself. A comprehensive account of this work is therefore more than welcome, in that it gives an idea of the immense scope of inquiries which have been investigated and of which records and technical reports are available. In recent years, since the creation of the Advisory Councils of the Imperial Institute in 1926, the Scientific and Technical Department has had considerably more scope; for these Councils, of which there is one for vegetable fibres, may propose and consider schemes of work for prosecution by the Institute and may advise on the best means of carrying them out. As a result of this, one of the main lines of investigation in the case of vegetable fibres has been the effect of sea-water on the life of ropes and twines. This work was commenced primarily in the interests of the sisal industry, but has since been enlarged to include New Zealand flax, Mauritius hemp and sannhemp. The results of this work have proved to be of the greatest value both to the pro. ducer and to the consumer, and have done much to advertise the extremely useful services which the Imperial Institute performs.

\section{The Colorado Potato Beetle}

THIs insect is a recent immigrant into Europe from North America, and has now become established over a large area of France. Its further spread into north-eastern France and into Belgium is a matter of importance to potato growers in England. The Ministry of Agriculture and Fisheries directs attention to the probability that examples of this beetle will reach southern England from time to time by direct flight. In such circumstances small outbreaks might readily occur, and the Ministry is accordingly anxious to obtain as early a notification as possible of the discovery of the pest in this country. Potato growers, especially those in Essex, Kent and Sussex, are asked to keep close watch on their crops, and to inform the Ministry immediately the presence of the beetle is suspected or discovered. A full description of the insect is given in the Ministry's Advisory Leaflet, No. 71. Any yellowish beetle with black stripes, or any red or reddish-yellow grub, that is found feeding upon potato leaves should be regarded with suspicion. When such beetles or grubs are discovered, specimens should be placed in a tin box (in which no holes should be punched) with a piece of potato leaf, and the box should be sent to the Ministry of Agriculture, 10 Whitehall Place, London, S.W.1, with a letter stating the exact place where the insects were caught and the name and address of the finder. No other steps should be taken until instructions are received from the Ministry ; it is especially important that the crop should not be sprayed or interfered with, as this is likely to cause the beetles to spread, and an outbreak possibly affecting only a few square yards may be distributed throughout a field. Apart from the specimens sent to the Ministry, no beetles or grubs should be removed. The object of these measures is to keep the insect confined to as small an area as possible, so that it may be eradicated without loss of time.

\section{Discovery : an African Number}

Discovery of June, in an opportune moment, is concerned almost exclusively with Africa. It opens, immediately after editorial notes and comments, with an article by Prof. C. G. Seligman on human types in tropical Africa. Prof. Seligman explains how it has come about that the usual classification of the native peoples of the continent is based on linguistics rather than on physical characters, and then sets out the distribution and characteristics of the major racial divisions in the tropical area. Dr. H. E. Hurst, in a study of the Upper Nile, discusses questions relating to water supply at the source, and indicates where there is necessity for further research. Of the remaining articles, two in particular require mention. Capt. William Hichens's account of demoniac possession is a valuable report by an eye-witness of a recent outbreak of Kupagawa na pepo ("ridden by demons"), which amounted almost to an epidemic in Mombasa and other towns of East Africa. He describes the various forms of demon dances by which the spirits were exorcised. In another article, G. A. Gardner, field director of the Archæological Committee of the University of Pretoria, describes the results of further excavations at Mapunggubwe on the south side of the Limpopo River. The partial excavation of a mound, which was found to consist of village refuse, confirms the results of previous excavation on an adjacent area which has been described by Prof. C. van Riet Lowe. He ascribed the earlier of the two occupations then discovered to the Sotho. This is regarded as the earliest trace of Bantu culture known in the Union. The mound excavated by Capt. Gardner was entirely Sotho. It had a depth of $20 \mathrm{ft}$. and consisted of about 40,000 tons of material. It was found to be centrally situated in a village from which had come the refuse of which it was composed. There was no iron, but copper ornaments, bangles and bracelets were plentiful. The burials were disarticulated with the skull on top of the bones. In several instances cow bones were associated with the human remains.

\section{World Power Conference}

ThE death last May of Mr. D. N. Dunlop, chairman of the International Executive Council of the World Power Conference and of the British National 